\title{
Effect of thermal processing on lycopene, beta-carotene and Vitamin C content of tomato [Var.UC82B]
}

\author{
Ishiwu Charles N. ${ }^{1,}$, , Iwouno, Jude O. ${ }^{2}$, Obiegbuna James E. ${ }^{1}$, Ezike Tochukwu C. ${ }^{3}$ \\ ${ }^{1}$ Department of Food Science and Technology, Nnamdi Azikiwe University, Awka- Nigeria \\ ${ }^{2}$ Department of Food Science and Technology, Federal University of Technology, Owerri-Nigeria \\ ${ }^{3}$ Department of Biochemistry, Caritas University, Amorji-Nike, Enugu-Nigeria
}

\section{Email address:}

nwaejaka@yahoo.com (Ishiwu C. N.)

\section{To cite this article:}

Ishiwu Charles N., Iwouno, Jude O., Obiegbuna James E., Ezike Tochukwu C.. Effect of Thermal Processing on Lycopene, BetaCarotene and Vitamin C Content of Tomato [Var.UC82B]. Journal of Food and Nutrition Sciences. Vol. 2, No. 3, 2014 , pp. 87-92. doi: $10.11648 /$ j.jfns.20140203.17

\begin{abstract}
The available lycopene, beta-carotene and vitamin C content of raw, boiled and fried tomato (Var.UC82B) were evaluated. Ripe tomato was purchased from Ogbete main market Enugu- Nigeria and the variety was identified at the Crop Science department, University of Nigeria Nsukka. It was sorted, washed and pulped using a blender. The pulp was divided into seven portions and labeled (A-G) Portion A was raw sample that served as a control since it was neither boiled nor fried. Portions B, C, and D were boiled for 2, 15 and 30minutes respectively. Portions E, F and G were fried in refined bleached and deodourized groundnut oil for 2, 15 and 30 minutes respectively. The seven samples were separately packaged in vial glass tubes and analyzed within three days from the time they were produced. Result shows that the three response variables evaluated were significantly $[\mathrm{P}<0.05]$ affected by either boiling or frying. The lycopene content significantly increased $[\mathrm{p}<0.05]$ as the period of boiling or frying increased between 2 and 30minutes. Boiling the pulp or frying it for 30 minutes increased the lycopene content from 24.2 to $32.9 \%$ respectively. However, both the beta-carotene and the Vitamin $\mathrm{C}$ content significantly [ $<<0.05]$ decreased as boiling or frying period increased between 2 and 30 minutes. The beta-carotene content decreased by $61.4 \%$, while the Vitamin C content decreased by $49.4 \%$ when the tomato pulp was boiled for 30 minutes. When the tomato pulp was fried for 30 minutes, the beta-carotene decreased by $63.6 \%$, while the vitamin $\mathrm{C}$ decreased by $50.0 \%[\mathrm{p}<0.05]$. It is therefore, advisable to boil or fry tomato before consumption for maximum absorption of its available lycopene. However, excessive heat treatment would have adverse effect on the beta carotene and vitamin $\mathrm{C}$ content of the tomato.
\end{abstract}

Keywords: Tomato, Boiled, Fried, Lycopene, Carotene

\section{Introduction}

Lycopene is a bioactive carotenoid found in many red fruits and vegetables such as tomatoes, watermelon, pink grapefruits, apricots and pink guava [1]. Animals including humans cannot synthesize lycopene. Therefore, they obtain lycopene exclusively from diets [2]. However, lycopene is synthesized in various isomeric forms by some plants and microorganisms [3]. Studies have shown that intake of lycopene-rich foods reduced risk of prostrate cancer $[4,5,6]$ Lycopene scavenges free radical which causes oxidative damage to cells [7]. Lycopene may improve male fertility because its consumption by men improved the morphology and mobility of sperm cells [8]. Lycopene is the most predominant carotenoid in human plasma compared to beta-carotene and other dietary carotenoids in tomato consuming populations [9]. Light, thermal and chemical reactions during processing affect lycopene [10, 11]. Heat processing of fruits and vegetables rich in lycopene makes the availability of lycopene higher than in the raw products $[12,13]$.

Tomato matrix disruption by mechanical homogenization or heat treatment of tomato increases lycopene bioavailability $[14,15]$. Oxidation and thermal degradation of lycopene occurred at high temperatures and processing times beyond 90 minutes [16, 17]. Similarly, it was reported that excessive heat treatment negatively affects the lycopene content of tomatoes [18]

Numerous studies have shown association between higher intakes of carotenoid - rich fruits and vegetables and 
reduced risk of cancer [19]. $\beta$-Carotene is an organic compound, a red-orange pigmented terpenoid that abounds in plants and fruits. It is a precursor of vitamin A.

Vitamin C (ascorbic acid) is found is many fruits and vegetables. It plays the role of an antioxidant and acts to neutralize free radicals $[20,21,22]$

This present research aims at subjecting tomato pulp to frying or boiling and thereafter evaluating the effect of these treatments on the lycopene beta carotene and vitamin $\mathrm{C}$ contents of the samples.

\section{Materials and Methods}

\subsection{Source of Raw Material}

Ripe tomato [Var. UC82B] was purchased from Nsukka main market and identified at the Department of Crop Science University of Nigeria Nsukka. Refined, bleached and deodourized groundnut oil was also bought from the same market.

\subsection{Sample Preparation}

The samples were prepared at the Department of Biochemistry Caritas University Amorji, Enugu. The tomato was sorted, washed, manually sliced and pulped using a blender [Turnar Corp. Shanga-Hai.Model No QBL$15 \mathrm{~L} 40$ ] at $12000 \mathrm{rpm}$ for 10 minutes. The pulp obtained was divided into seven portions weighing $200 \mathrm{~g}$ each and labeled as samples A-G. Sample A served as the control sample, it did not receive thermal treatment. Samples B, C and D were separately boiled for 2, 15 and 30 minutes respectively. Samples E, F and G were separately deep fatfried in refined groundnut oil for 2, 15 and 30minutes respectively. The samples were separately packaged in glass bottles stored in a refrigerator and analyzed within three days from the time they were processed.

\section{Analysis}

The raw and processed samples were subjected to the following analysis within three days of sample preparation:

\subsection{Lycopene Content Determination}

A $1 \mathrm{~g}$ of sample was weighed into a clean beaker and macerated with $20 \mathrm{ml}$ of $1 \%$ metaphosphoric acid solution and filtered. Also, $10 \mathrm{ml}$ of metaphosphoric acid solutions was used to wash off the residue. The resultant residue was macerated with $20 \mathrm{ml}$ of acetone, then filtered and the absorbance of the filtrate read at $440 \mathrm{~nm}$ against acetone as blank using a Spectrophotometer [Pye Unicam double beam spectrophotometer]. The analysis was replicated three times and the mean calculated. The concentration of lycopene was calculated [23]

$$
\text { Lycopene }[7 n g / 100 \mathrm{~mL}]=\frac{\text { Mean absorbance } \mathrm{x} \text { dihution factor }}{\text { Slope }}
$$

The slope (0.095) was calculated from the standard curve of lycopene plotted using concentration of lycopene against absorbance.

\subsection{Beta-Carotene Content Determination}

A $1 \mathrm{~g}$ sample was weighed into a beaker and macerated with $10 \mathrm{ml}$ mixture of acetone and $\mathrm{n}$-hexane $(1: 1)$ and filtered. $10 \mathrm{ml}$ of $50 \%\left(\mathrm{NH}_{4}\right)_{2} \mathrm{SO}_{4}$ solution was added, vigorously shaken and allowed to settle. Then the upper layer was collected and the absorbance read in Pye Unicam double beam Spectrophotometer at $450 \mathrm{~nm}$ against hexane as blank [24]

$$
\text { Bta }- \text { carotene }\left[\mathrm{mg}[100 \mathrm{ml}]=\frac{\text { Masn absorbance } \mathrm{x} \text { dilution }}{\text { Slope }}\right.
$$

The slope (1.249) was obtained from the standard curve of beta-carotene plotted using concentration of betacarotene against absorbance.

\subsection{Vitamin C Content Determination}

A $1 \mathrm{~g}$ samples was weighed into a beaker and macerated with $20 \mathrm{ml}$ of $0.4 \%$ oxalic acid solution and filtered. Then $1 \mathrm{ml}$ filtrate was pipetted into a test tube and $0.2 \mathrm{ml}$ of $0.01 \%$ methylene blue solution added. Also $1 \mathrm{ml}$ of acetate buffer $\mathrm{pH} 4.2$ was added into the solution and made up to $5 \mathrm{ml}$ mark using distilled water. Absorbance of the solution was read using Spectrophotometer [Spectronic D2] vitamin $\mathrm{C}$ was calculated [25]

$$
\text { Vitamin } C[\mathrm{mg} / 100 \mathrm{ml}]=\frac{\text { Mean absorbance } \mathrm{x} \text { dilution factor }}{\text { Slope }}
$$

The slope (0.0693) was calculated from the standard curve of vitamin $\mathrm{C}$ against absorbance.

\subsection{Statistical Analysis}

Data obtained from the triplicate determinations of the three response variables were analyzed using SPSS version 16.0 through One-Way Analysis of Variance [ANOVA]. The means that differed significantly were separated using Duncan's multiple range (DMR) test and LSD. Significant difference between means of the samples was determined at $\mathrm{P}<0.05$

\section{Results}

The phyto-chemical composition (lycopene, betacarotene and vitamin $\mathrm{C}$ content) of boiled and fried tomato pulp are presented in Table 1. Raw tomato pulp contained lycopene, beta-carotene and vitamin $\mathrm{C}$ in varied concentrations as $12.4 \pm 0.01, \quad 15.7 \pm 0.01$ and $49.8 \pm 0.014 \mathrm{mg} / 100 \mathrm{ml}$ respectively. Two minutes boiling increased lycopene from $12.4 \pm 0.01$ to $13.9 \pm 0.01 \mathrm{mg} / 100 \mathrm{ml}$ and decreased beta carotene from $15.7 \pm 0.01$ to $12.2 \pm 0.01 \mathrm{mg} / 100 \mathrm{ml}$ and also decreased vitamin $\mathrm{C}$ from $49.8 \pm 0.014$ to $42.2 \pm 0.14 \mathrm{mg} / 100 \mathrm{ml}$. Extending the boiling 
time to 15 minutes further increased the lycopene to $14.8 \pm 0.04 \mathrm{mg} / 100 \mathrm{ml}$ but decreased the beta carotene and vitamin $C$ to $6.6 \pm 0.00$ and $33.7 \pm 0.24 \mathrm{mg} / 100 \mathrm{ml}$ respectively. Boiling the paste for 30 minutes increased the lycopene to $16.4 \pm 0.05 \mathrm{mg} / 100 \mathrm{ml}$ but reduced the beta carotene and vitamin $\mathrm{C}$ to $5.7 \pm 0.140$ and $25.2 \pm 0.00$ $\mathrm{mg} / 100 \mathrm{ml}$ respectively. Similarly, frying the pulp for 2 minutes increased the lycopene to $14.0 \pm 0.01 \mathrm{mg} / 100 \mathrm{ml}$, but decreased the beta-carotene and vitamin $\mathrm{C}$ content to $15.2 \pm 0.01$ and $36.9 \pm 0.00 \mathrm{mg} / 100 \mathrm{ml}$ respectively, while 15 minutes frying increased the lycopene to $14.9 \pm 0.04$ $\mathrm{mg} / 100 \mathrm{ml}$ similar to boiling reduced the beta-carotene and vitamin $C$ to $9.17 \pm 0.00$ and $22.77 \pm 0.03 \mathrm{mg} / 100 \mathrm{ml}$ respectively and Again, 30 minutes frying increased the lycopene to $18.50 \pm 0.10 \mathrm{mg} / 100 \mathrm{ml}$ and reduced the betacarotene and vitamin $\mathrm{C}$ to $6.1 \pm 0.06$ and $20.9 \pm 0.07$ $\mathrm{mg} / 100 \mathrm{ml}$ respectively

\section{Discussion}

Table 1 Shows the Phyto-chemical composition of raw and thermally processed tomato [Var.UC82B] samples. The lycopene content of the tomato pulp significantly increased $[\mathrm{P}<0.05]$ when boiled or fried. The available lycopene content progressively increased as boiling or frying period was increased from 2 to $30 \mathrm{~min}$. Figure 1 exhibits the lycopene content of both boiled and fried tomato samples.

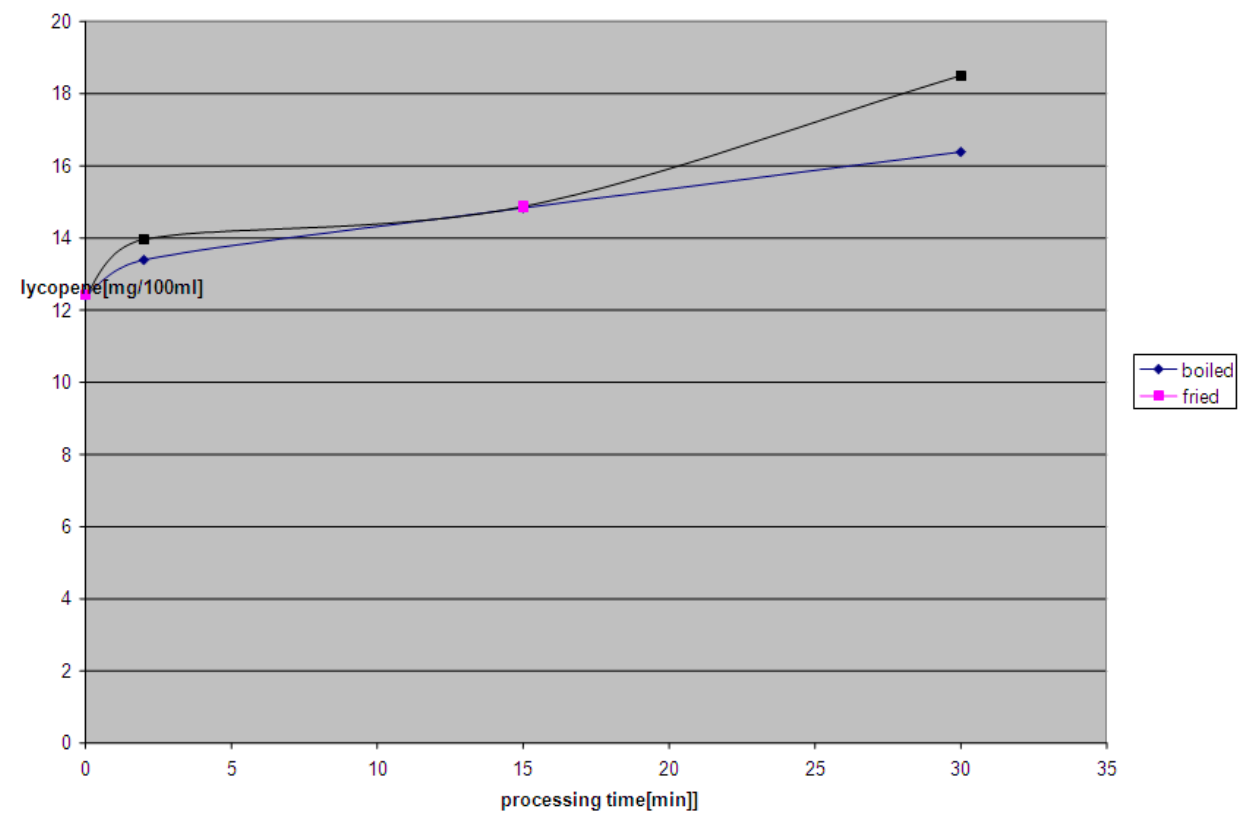

Fig. 1. Effect of Period of Processing on lycopene Content of Tomato

Table 1. Lycopene, beta carotene and vitamin C content of the samples

\begin{tabular}{|c|c|c|c|c|c|}
\hline $\begin{array}{l}\text { Type of } \\
\text { treatment }\end{array}$ & Sample Code & $\begin{array}{l}\text { Processing } \\
\text { Time (min.) }\end{array}$ & Lycopene (mg/100ml) & $\begin{array}{l}\text { Beta-carotene } \\
(\mathbf{m g} / \mathbf{1 0 0 m l})\end{array}$ & $\begin{array}{c}\text { Vitamin C } \\
(\mathrm{mg} / 100 \mathrm{ml})\end{array}$ \\
\hline \multirow[t]{2}{*}{ Raw } & A & 0 & $12.4^{\mathrm{a}} \pm 0.01$ & $15.7^{\mathrm{a}} \pm 0.01$ & $49.8^{\mathrm{a}} \pm 0.014$ \\
\hline & $\mathrm{B}$ & 2 & $13.9^{\mathrm{b}} \pm 0.01$ & $12.2^{\mathrm{b}} \pm 0.01$ & $42.2^{\mathrm{b}} \pm 0.14$ \\
\hline \multirow[t]{3}{*}{ Boiled } & $\mathrm{C}$ & 15 & $14.8^{\mathrm{c}} \pm 0.04$ & $6.6^{\mathrm{c}} \mathrm{c} \pm 0.00$ & $33.7^{c} \pm 0.24$ \\
\hline & $\mathrm{D}$ & 30 & $16.4^{\mathrm{d}} \pm 0.05$ & $5.7^{\mathrm{d}} \pm 0.140$ & $25.2^{\mathrm{d}} \pm 0.00$ \\
\hline & $\mathrm{E}$ & 2 & $14.0^{\mathrm{b}} \pm 0.01$ & $15.2^{\mathrm{e}} \pm 0.01$ & $36.9^{\mathrm{e}} \pm 0.00$ \\
\hline \multirow[t]{2}{*}{ Fried } & $\mathrm{F}$ & 15 & $14.9^{c} \pm 0.04$ & $9.2^{f} \pm 0.00$ & $22.8^{\mathrm{f}} \pm 0.03$ \\
\hline & G & 30 & $18.50^{\mathrm{e}} \pm 0.10$ & $6.1^{g} \pm 0.06$ & $20.9^{\mathrm{g}} \pm 0.07$ \\
\hline
\end{tabular}

Values are means of triplicate determinations \pm SD. Values in the same column bearing different superscripts are significantly different $[\mathrm{P}<0.05]$

Boiling the pulp for $2 \mathrm{~min}$ increased the available lycopene content by $10.9 \%$, while $24.2 \%$ increase in lycopene content was observed by extending the boiling period to $30 \mathrm{~min}$.
Similarly, frying the tomato pulp for 2minutes significantly increased $[\mathrm{P}<0.05]$ the available lycopene content by $11.1 \%$, while frying it for 30 minutes increased the available lycopene content by $32.9 \%$. The observed 
increase in available lycopene content of tomato pulp as a result of boiling or frying is in agreement with earlier reports that lycopene in the natural trans form is poorly absorbed from raw tomato when consumed [15, 12] Similarly, lycopene is less absorbed from fresh tomatoes than cooked tomatoes [13] Therefore, thermally processed tomato products could be the best food sources of lycopene. Men seeking to avoid prostate enlargement may increase their intakes of raw tomato.

Figure 2 shows the curve of $\beta$-carotene of boiled and fried tomato samples at varied processing periods. The $\beta$ carotene content of tomato decreased with increase in period of boiling and frying. There was a significant
$[\mathrm{P}<0.05]$ decrease in $\beta$-carotene content as a result of boiling tomato pulp for 2 minutes and further decrease occurred by extending the boiling time to 30 minutes. Similarly, frying tomato pulp for 2 minutes decreased its $\beta$ carotene content, while frying it for $30 \mathrm{~min}$ caused more decrease in its $\beta$-carotene content. This sharp decrease in $\beta$ carotene content of the samples as boiling or frying time increased suggests that $\beta$-carotene is a heat labile compound, and could be more available in raw tomato than the processed counterpart.

The Vitamin C content of tomato pulp decreased as both boiling and frying period increased as shown in Table 1 and Figure 3.

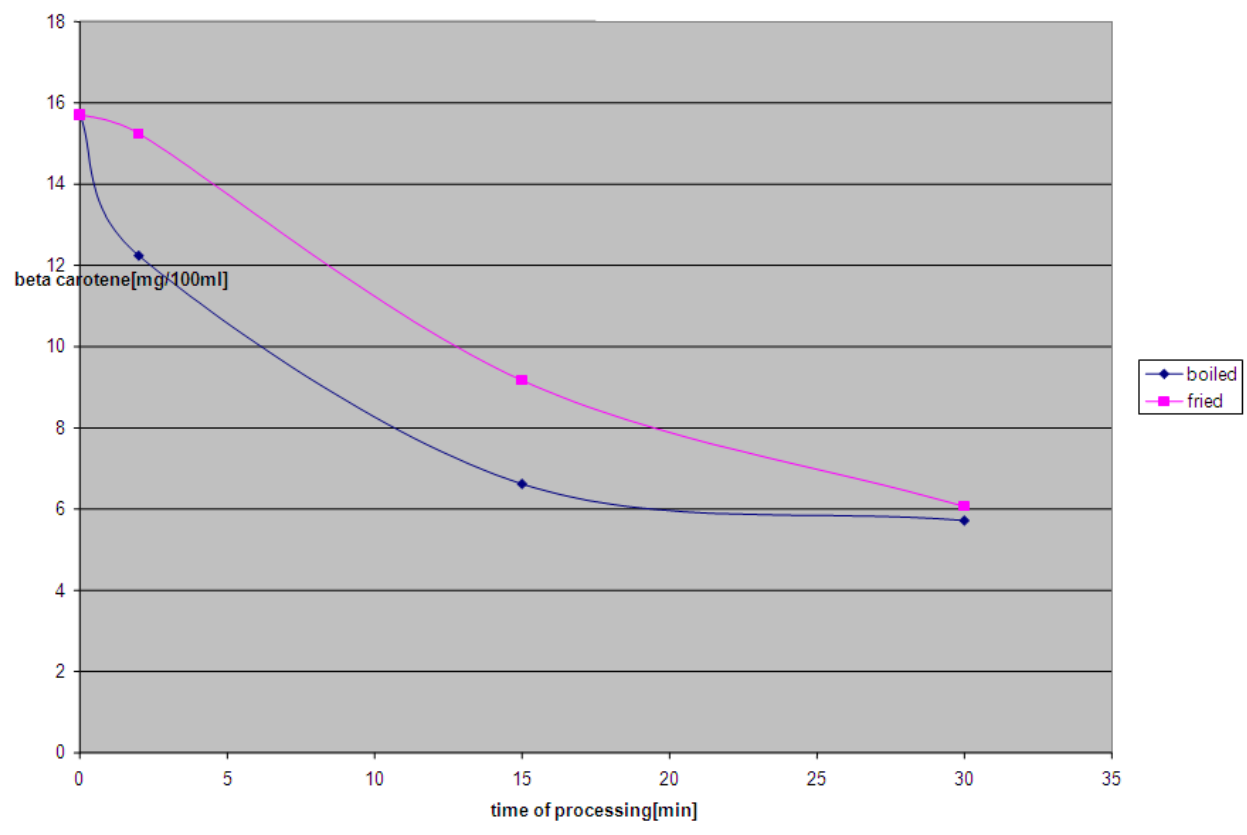

Fig.2. Effect of Period of Processing on Beta - carotene Content of Tomato

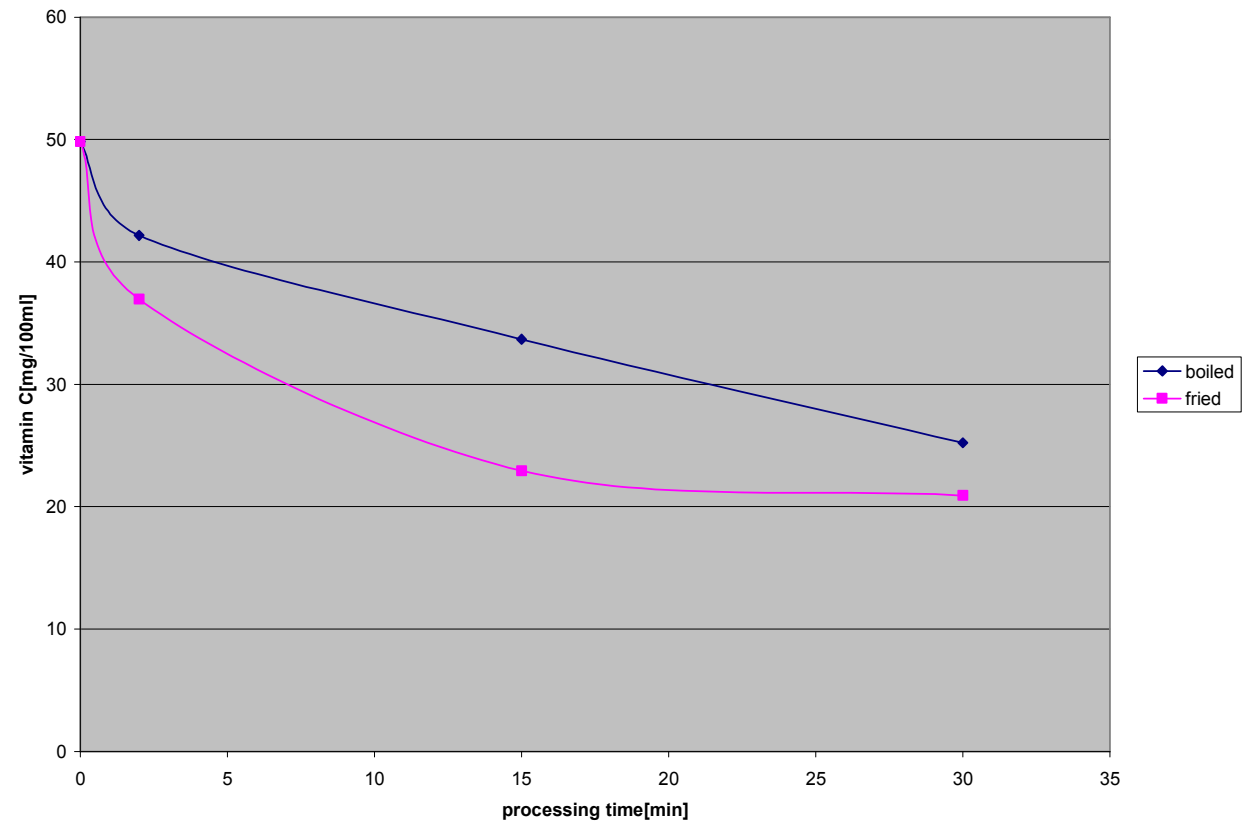

Fig. 3. Effect of Period of Processing on Vitamin C content of Tomato 
Vitamin C progressively decreased as the processing times increased therefore, suggesting that it does not require excessive heat treatment. The decrease in Vitamin $\mathrm{C}$ content was progressive as boiling time progressed from 2 to 30 minutes. Also, frying tomato pulp caused a progressive decrease in value of its Vitamin $\mathrm{C}$ content, in a similar fashion caused by boiling but had more adverse on vitamin $\mathrm{C}$. There is a significant variation in Vitamin $\mathrm{C}$ content $[\mathrm{P}<0.05]$ between the tomato samples boiled for $30 \mathrm{~min}$ and its counterpart fried for $30 \mathrm{~min}$. Frying the pulp for $30 \mathrm{~min}$ resulted in higher loss of vitamin C. thermal processing of tomato should be carefully controlled to retain much of this vitamin in the finished product.

\section{Conclusion}

$\beta$-Carotene and vitamin $\mathrm{C}$ content of tomato pulp became unavailable as the tomato pulp is subjected to thermal processing (boiling or frying) However, thermal processing makes the lycopene more available in processed tomato. This nutrition information could be a guide to processors and consumers of tomato products.

\section{Acknowledgement}

The authors highly appreciate the assistance rendered by the laboratory technologists at Department of Biochemistry university of Nigeria Nsukka during the execution of this research.

\section{References}

[1] Pohar KS, Gong MC, Bahnson R, Miller EC and Clinton SK Tomatoes, Lycopene and Prostate Cancer. World J Urol. 2003; $21: 9-14$.

[2] Tapier H, Townsend DM and Tew KD The Role of Carotenoids in the Prevention of Human Pathologies and Biomed Pharmacother 2004; 58: 100 -110.

[3] Hadley CW, Clinton SK and Schwartz SJ How the Consumption of Processed Tomato Products Enhances Plasma Lycopene Concentrations in Association with a Reduced Lipoprotein Sensitivity to Oxidative Damage. $J$ Nutr. 2003; 133: 727-32.

[4] Giovannucci E, Rimm EB, Liu Y, Stampfer MJ and Willett WC A Prospective Study of Tomato Products, Lycopene, and Prostate Cancer Risk. J. National Cancer Inst. 1995; 94: $391-8$.

[5] Narisaw AT, Fakaura Y, Hasebe M, Ito M, Aizawa R, Murakoshi M, Uemura S, Khachik and Nishino $H$ Inhibitory Effects of Natural Carotenoids: Alpha-carotene, Beta-carotene, Lycopene and Lutein on Colonic Aberrant Crypt Foci Formation in Rats. Cancer Lett 1996; 107: 137 $-142$.

[6] Martinez Ferrer, Verghese M, Walker LT, Shackeford L, Chawan CB and Jhala N Lycopene Reduces Azoxymethane- induced Colon Tumors in Fisher 344 Rats. Nutr Res 2006; 26: $84-91$

[7] Gupta NP and Kumar R Lycopene Therapy in Idiopathic Male Infertility a Preliminary Report. Int Uro Nephrol 2002; 34: 369-372.

[8] Agarwal S and Rao AV Tomato Lycopene and its Role in Human Health and Chronic Diseases. J. Am Coll Nutr 2000; 163 [6]:739 - 744.

[9] Tanumihardjo S A Furr HC Amendee Manseme O and J A Olson Retinal Ester (vitamin A Ester) and Carotenoid Composition in Human Liver. Int J. Vitamin Nutr.1991; 121: $1613-1621$.

[10] Shi J, Mauguer ML, Liptay A and Niekamp F Lycopene Degradation and Isomerization in Tomato Dehydration. Food Res 1999; 32: 15-21.

[11] Goula AM, Adamopoulos KG, Chatzitakis P and Nikas VA Predicttion of Lycopene Degradation During a Drying Process of Tomato Pulp. Journal of Food Eng 2006; 74: 37 $-46$.

[12] Rao AV and Agarwal S Role of Antioxidant Lycopene in Cancer and Heart Disease. J. Am Coll Nutr.2000; 19 [3]: $563-569$.

[13] Donaldson MS Nutrition and cancer: A review of the evidence for anti-cancer diet. Nutr J 2004; 3 -10.

[14] Van het, Hof KH, deBoer BC, Tijburg, LB Lucius, BR, Zip I West CE, Hautvast JG, Weststrate JA Carotenoid Bioavailability in Humans from Tomatoes Processed in Different Ways determined from the carotenoid response in the triglyceride-rich lipoprotein fraction of plasma after a single consumption and in plasma after four days of consumption. J. Nutr. 2000; 130: 1189 - 96.

[15] Dewanto VW, Adom KK and Liu RH Thermal Processing Enhances the Nutritional Value of Tomatoes by Increasing Total Antioxidant Activity. J. Agric. Food Chem. 2002; 50: 3010 - 3014.

[16] Takeoka, GR, Dao L, Flessa S, Gillespie DM, Jewell WT, Huebner B, Bertow D and Ebeler SE Processing Effects on Lycopene content and Antioxidant Activity of Tomatoes. $J$. Agric. Food Chem. 2001; 49: 3713 - 3717.

[17] Seybold C, Frohlich K, Bitsch R, Otto K and Bohm V Changes in Contents of Carotenoids and Vitamin E During Tomato Processing. J.Agric. Food Chem. 2004; 52: 5 -10.

[18] Sahlin E, Savage GP and Lister CE Investigation of the Antioxidant Properties of Tomatoes after Processing. J Food Compo Anal 2004; 17:35 - 47.

[19] Ziegler RG Vegetables, Fruits and Carotenoids and the Risk of Cancer. Am J. Clin Nutr. 1991; $53: 251$ - 259

[20] Bendich, A "Antioxidant Micronutrients and Immune Response". In Bendich, A. and Chandra, R.K. [eds.]. Micronutrients and immune functions. N.Y. Academy of Sciences, N.Y. 1990; 63 - 76.

[21] NRC Recommended Dietary Allowances, National Research Council [NRC] $10^{\text {th }}$ edn. National Academic Press Washington, DC.1989; p.24 
[22] Gorton HC and Javis K The Effectiveness of Vitamin C in Preventing and Relieving the Symptoms of Virus-induced Respiratory Infections, J. Man, Phys. Ther. 1999; 22 (8): $530-3$.

[23] Snell FD and Snell CT Colometric Methods of Analysis. $3^{\text {rd }}$ Edition, Vol. 3. D. Van Nostrand Company Inc., York, 1958; $37-38$.
[24] Alexander RR and Griffiths JM Basic Biochemical Methods. $2^{\text {nd }}$ Edition Wiley \& Sons Inc, New York; 1993; 50 - 60.

[25] Pearson D Laboratory Technique in Food Analysis. Butterworth and Co. Publishing Ltd. 1976; p. 233 